\title{
O silêncio é de ouro e a palavra é de prata? Considerações acerca do espaço da oralidade em educação de jovens e adultos
}

\author{
Janine Fontes de Souza \\ Universidade do Estado da Bahia, Departamento de Ciências Humanas e Tecnologias
}

Kátia Maria Santos Mota

Universidade do Estado da Bahia, Departamento de Educação

\author{
Iniciando o diálogo \\ A palavra não foi feita para enfeitar, brilhar como \\ ouro falso; a palavra foi feita pra dizer. \\ Graciliano Ramos, 1948.
}

\section{Introdução}

Somos constituídos eminentemente pela força criadora da linguagem e é justamente ela que nos caracteriza como "seres humanos"; a criatividade lingüística faz com que nos destaquemos em meio a todos os outros animais. Estes possuem voz (phoné) e com ela exprimem dor e prazer, mas o homem possui a palavra (lógos) - o signo lingüístico composto de significante (imagem sonora) e significado (representação mental) -, componente gerador da linguagem verbal como instituição social (Saussure, 1975).

Conversamos, lemos, escutamos nossos interlocutores, trocamos idéias, vemos televisão, ouvimos rádio, acessamos a Internet, constituimo-nos socialmente pela linguagem, a qual é concebida em três di- mensões: como representação do mundo e do pensamento, como instrumento de comunicação e como forma de ação ou interação (Koch, 2003). Pelos atos de fala, podemos designar e qualificar as coisas, praticamos ações com palavras ditas e não ditas, exercemos o poder da fala intencionados em causar efeitos de sentidos múltiplos nos outros; enfim, a fala é um ato performativo (Austin, 1965). Nesse sentido, Geraldi (1984, p. 43) sintetiza: "a linguagem é uma forma de interação: mais do que possibilitar a transmissão de informação de um emissor a um receptor, a linguagem é vista como um lugar de interação humana: através dela o sujeito que fala pratica ações que não conseguiria praticar a não ser falando".

Os gregos, ao se referirem à linguagem, utilizavam duas palavras: mythos e lógos. A primeira representava as narrativas sobre a história dos deuses, dos homens, do mundo; era a palavra mágica e encantatória que faz à vida o que ainda não se fez. Nesse sentido, a força criadora da palavra, por excelência, materializa-se na sua magnitude nos textos bíblicos do Gênesis, nos quais a palavra cria a vida: "Deus disse: Faça-se a luz! e a luz foi feita". Então "Deus 
disse: Façamos o homem à nossa imagem e semelhança [...]" (Gênesis 1: 3 e 26). A segunda palavra, lógos, manifesta-se como uma síntese de três idéias: fala/palavra, pensamento/idéia e realidade/ser. Lógos é a palavra racional em que se exprime o pensamento que conhece o real, é discurso (argumento e prova), pensamento (raciocínio e demonstração) e realidade (coisas, nexos e ligações universais e necessárias entre os seres) (Chauí, 2003).

O espaço social é, então, criado pelas vozes que nele operam, construídas, na concepção de Bourdieu (1998), pelo habitus de cada grupo social durante o processo de formação do indivíduo, ao mesmo tempo em que transcende a sua história pessoal ao ser receptor da herança cultural da sua comunidade local. O habitus constitui-se de estruturas estruturadas a serem transformadas em estruturas estruturantes, "história transformada em natureza". Assim, as vozes sociais são organizadas em padrões de produção e recepção, mas também de opressão - repressão e emancipação.

A fala (ou o uso da língua, em geral) é um pouco similar à troca de presentes: não é suficiente que nossa fala faça sentido, também é necessário que ela se "inscreva" num padrão de fala, ou seja, que a fala se tome como fala$d a$, que a fala "se auto-evidencie", digamos assim. (Mey, 2001, p. 46)

Os discursos sociais vão, assim, (des)organizandose historicamente com e pela interação, por processos dialéticos e dialógicos. Bakhtin (1990) retoma o conceito saussureano de signo lingüístico, reconhecendo a natureza eminentemente social da linguagem, mas critica a excessiva concentração no enfoque das questões da langue, salientando que o caráter de abstração inerente ao sistema lingüístico não revela os usos sociais da língua; em contrapartida, prioriza o direcionamento para a parole, pois esta organiza-se a partir das condições contextuais da comunicação que são implicitamente ligadas às estruturas sociais. Segundo Bakhtin, o sujeito emerge do outro a partir da enunciação (interação verbal) e não do enunciado em si; a partir de experiências dialógicas com outros "eus" é que o "eu" do sujeito se organiza para se tornar "autor" de si mesmo. A incompletude é inerente ao sujeito; a alteridade torna-se fundamental para a constituição de identidades sociais; a noção do eu é sempre social, dividindo-se em três categorias: o eu-para-mim, o eu-para-o-outro e o outro-para mim.

Os estudos de Bakhtin comungam com as idéias de Vygotsky (1989), pois ambos sustentam a argumentação de que a linguagem, historicamente determinada, produz sentidos a partir da interlocução, no interior da qual os interlocutores se constituem e são constituídos. A linguagem e o pensamento na concepção desse autor estão intimamente conectados, sendo que o processo individual de formação da consciência só toma forma a partir da interação; o interpessoal é condição para o intrapessoal. A linguagem, nas concepções de Bakhtin e de Vygotsky, torna-se o lugar da interação, da negociação de sentidos, da representação de papéis, da constituição de identidades.

\footnotetext{
O significado das palavras é um fenômeno de pensamento apenas na medida em que o pensamento ganha corpo por meio da fala, e só é um fenômeno de fala na medida em que esta é ligada ao pensamento, sendo iluminada por ele. É um fenômeno do pensamento verbal, ou da fala significativa - uma união da palavra e do pensamento. (idem, p. 4)
}

Essa dimensão social do discurso, manifestada pela fala individual, muito raramente é reconhecida pela escola. As práticas escolares preocupam-se, sobretudo, com atividades estritamente pedagógicas que, ignorando as trajetórias pessoais dos seus protagonistas, lhes impõem modelos de ensino e conteúdos justamente produzidos para a reprodução de saberes privados das classes dominantes. Assim, acabam elegendo determinados aspectos como imprescindíveis, ao mesmo tempo em que ignoram tantos outros tidos como menos importantes, baseando-se em preconceitos, discriminações, verdades incontestáveis, dogmáticas, que são perpetuadas ao longo dos tempos. 
Como instituição que introduz os grupos iletrados ou semiletrados às práticas letradas de prestígio, a escola não reconhece as condições de produção textual dos alunos na dinâmica interacional (tempo, lugar, papel social, objetivos da interlocução, entre outros). Portanto, optar pela problematização das condições de produção contribui para inscrever o trabalho na sala de aula com base na dialogicidade. A condição em que a linguagem se produz possibilita a ruptura ou a conservação da situação discursiva que se estabelece entre professores e alunos em sala de aula.

A postura homogeneizante da escola não abarca a diversidade sociocultural dos alunos, patrimônio cultural que se sustenta na tradição de um conjunto de habitus responsável pela produção dos discursos de identidade marcados pelas diferenças de gênero, etnia, trabalho, filiação religiosa, territórios geográficos, entre outras. Assim, faz-se necessária a compreensão, por parte do professor, de que o processo educacional se configura, na maioria das vezes, como uma ação contínua de organização da própria identidade em comunhão com os demais. Tal constatação é extremamente importante, sobretudo quando se trata de classes de educação de jovens e adultos (EJA), as quais recebem aprendizes que experimentam o momento mágico do "rito de passagem" da tradição de oralidade (no microespaço da comunidade local) para o mundo grafocêntrico (no macroespaço da comunidade global), na intenção de elaborar um novo patamar de identidade, ao inserir-se ativamente no mundo letrado.

Nesse contexto, considerando que os jovens e adultos, diferentemente das crianças, já trazem trajetórias de vida sedimentadas, a escola deveria reconhecer e acolher as tradições de oralidade trazidas pelas culturas de origem e integrá-las às práticas de letramento propostas pela escola. Essas inquietações levaram-nos a questionar as classes de EJA sobre o espaço destinado ao trabalho pedagógico direcionado à oralidade, no tocante à construção da competência comunicativa dos sujeitos ali envolvidos. Algumas questões norteadoras inspiraram-nos a escrever este texto: que espaço é destinado à oralidade na pedagogia de EJA? Que aspectos da oralidade são tomados como ensináveis? Há, explicitamente, uma intenção pedagógica direcionada ao tratamento do texto oral? Que tipos de textos orais circulam no cotidiano escolar? Como se configuram as práticas de interação na sala de aula? Até que ponto o discurso pedagógico promove ou reprime o diálogo - interação?

\section{Na escola e na vida: quem tem direito à fala?}

Estudos etnográficos na área da linguagem e educação (Heath, 1994; Philips, 1993; Ogbu, 1991; Wells, 1986) traduzem o distanciamento entre as microculturas da comunidade familiar e da comunidade escolar como fator primordial determinante do fracasso escolar. Nessa mesma direção, pesquisadores brasileiros vêm corroborando essa realidade apontando para o descompasso entre as práticas discursivas que circulam dentro e fora da escola e suas implicações no processo de ensino-aprendizagem da leitura e da escrita (Bortoni-Ricardo, 2005; Kleiman, 2001; Magalhães, 2001; Cavalcanti, 2001; Soares, 2003). A necessidade de reconhecer o ambiente de origem do aluno, a "ecologia lingüística" da sua comunidade, torna-se fundamental para promover o diálogo em sala de aula, considerando que a aprendizagem se processa pela interação (ou "inter-ação") entre os interlocutores e seus textos orais e escritos.

Nas classes de EJA essa questão torna-se ainda mais enfática considerando que se trata de alunos adultos, homens e mulheres, providos de uma competência comunicativa (com base predominante na oralidade) satisfatória para os ambientes familiares nas esferas privadas da vida social; entretanto, quando se deslocam para a escola, são quase sempre infantilizados com textos de leitura e escrita que não condizem com suas experiências de vida. Isso explica o relato de uma trabalhadora doméstica, de 43 anos, que expõe a razão por ter abandonado a escola: "Não dou pra essas coisas de escola, minha cabeça faz muita confusão quando me dão aquelas coisas bobas pra ler e eu não consigo. Prefiro ir pra igreja. Lá na igreja eu 
converso as coisas da minha vida" (NC, entrevista out. 2001, em Mota, 2002). Esse seria, com certeza, o depoimento de muitos outros jovens e adultos que trocaram a escola pela igreja, ou, pela rua, pelo bar, pelo crime. Falta à escola o processo de mediação, tão fortemente apontado por Vygotsky (1989), como competência docente decisiva para estabelecer a ponte entre os conteúdos de vida e os de escola.

O diálogo entre educadores e educandos aparece em Freire (1988) como o "encontro dos homens, mediatizados pelo mundo, para pronunciá-lo, não se esgotando, portanto, na relação eu-tu" (p. 78). É a partir de uma tomada de consciência das coisas que acontecem ao seu redor (mundo-realidade) que o homem vai interagir nessa realidade, na qual ele é agente transformador, na medida em que também é transformado dentro das condições que lhe são apresentadas. A partir das relações do homem com a realidade, resultantes de estar com ela e estar nela, por meio de atos de criação, recriação e decisão, vai ele dinamizando o seu mundo, dominando a realidade, humanizando-a. Vai acrescentando a ela algo de que ele mesmo é fazedor; nesse instante, a transformação acontece por conta das leituras que os homens fazem do mundo como resultante da interação com seus pares.

O grande desafio educacional traduz-se no ajudar a gestar um homem enquanto sujeito pleno de seu desejo, de suas transformações, um sujeito no qual o sentido não se encerre - mas se inicie; não alguém assujeitado, mas um "sujeito situado" em seu tempo e espaço, dotado de um envolvimento tal com o universo que o cerca, que, na medida em que constitui o seu sentido próprio pelas suas ações, também ajuda a significar todo o mundo.

A proposta é a de conceber um sujeito que, sendo um eu para-si, condição de formação da identidade subjetiva, é também um eu para-o-outro, condição de inserção dessa identidade no plano relacional responsável/responsivo, que lhe dá sentido.

Só me torno eu em outros eus. Mas o sujeito, ainda que se defina a partir do outro, ao mesmo tempo o define, é o "outro" do outro: eis o inacabamento constitutivo do ser, tão rico de ressonâncias filosóficas, discursivas e outras.

(Sobral, 2005, p. 22)

Até que ponto, então, o discurso pedagógico se inscreve nessa proposta? Analisando os efeitos de promoção ou repressão do diálogo nas práticas interacionais, Orlandi (2003) fundamenta-se em dois processos lingüísticos - o parafrástico e o polissêmico para descrever três tipos de discurso: o lúdico, o polêmico e o autoritário. O lúdico caracteriza-se pela predominância da "polissemia aberta", ou seja, a falta de convergência de sentidos entre os interlocutores, a qual inviabiliza o processo de interação (de forma exagerada seria o "non-sense"); o polêmico privilegia o uso de perspectivas diferenciadas de ver o objeto, mantendo a "polissemia controlada" na qual a posição dialógica pode ser negociada; o autoritário elege a paráfrase como estratégia discursiva, ou seja, prevalece a "polissemia contida" na qual não há interlocutores de fato, pois se sustenta no processo de “inculcação" de significados partindo daquele que detém maior poder social. Seguindo essa categorização, o discurso pedagógico é visto como predominantemente autoritário, pois "mais do que informar, explicar, influenciar ou mesmo persuadir, ensinar aparece como inculcar" (idem, p. 17). Essa postura ratifica o que Freire (1988, p. 79) apresentava ao criticar o modelo de "educação bancária".

[...] o diálogo é uma exigência existencial. E, se ele é o
encontro em que se solidarizam o refletir e o agir de seus
sujeitos endereçados ao mundo a ser transformado e huma-
nizado, não pode reduzir-se a um ato de depositar idéias de
um sujeito no outro, nem tampouco tornar-se simples troca
de idéias a serem consumidas pelos permutantes.

O espaço da sala de aula caracteriza-se pela instauração ou não da possibilidade de transformar-se num lugar onde se desenvolva o conhecimento e a integração cultural. A relação professor/aluno é, sem dúvida, uma relação assimétrica, pois se manifesta a partir do jogo de relações de poder inerente ao papel social que cada um desempenha. Uma pessoa investida 
do papel de professor adquire poder de determinar ações aos alunos, e estes, por sua vez, legitimam esse poder, pois trazem de casa ou adquirem rapidamente na escola a imagem do professor como autoridade.

Não só os conteúdos escolares, mas também as variedades lingüísticas presentes na performance do professor marcam, ainda mais, a dificuldade de interação dialógica em sala de aula. O professor, como agente do controle social, adota uma variante lingüística muitas vezes distante das normas populares com as quais os alunos se identificam. As relações interativas, nesse sentido, dão-se dentro de uma conjuntura na qual o domínio da "língua legítima" se torna uma forte moeda de troca nas relações de sobrevivência, instituindo dessa forma um mercado lingüístico no qual os "preços" são definidos pelos grupos de posse dessa competência lingüística, cujas capacidades de produção são socialmente classificadas, configurando ao mesmo tempo a capacidade de apropriação e sua apreciação.

O que circula no mercado lingüístico não é a língua, mas discursos estilisticamente caracterizados, ao mesmo tempo do lado da produção, na medida em que cada locutor transforma a língua comum num idioleto, e do lado da recepção, na medida em que cada receptor contribui para produzir a mensagem que ele percebe e aprecia, importando para ela tudo o que constitui sua experiência singular e coletiva. (Bourdieu, 1998, p. 25)

Que chances tem o aluno em EJA, sendo portador de uma variante lingüística desprestigiada, de se posicionar em sala de aula como cidadão falante? Consideramos que, ao falarmos, colocamos em jogo tudo o que somos e o que sabemos sobre o mundo, sobre a linguagem, sobre as relações pessoais, sobre o cotidiano e sobre o poder que perpassa as interações. Dessa forma, de acordo com Geraldi (1995), o ato de fala configura-se em três desafios a serem enfrentados pelo falante: o primeiro é ter o que dizer, é mobilizar todo o seu conhecimento de mundo, articulálo com as próprias crenças pessoais, com os próprios conceitos e preconceitos, herdados ou adquiridos. O segundo é "querer dizer" o que se "tem a dizer", é desejar expressar-se, é reconhecer-se digno do dom da palavra ou do direito à palavra, é acreditar que o dito ou não dito pode marcar sua presença.

Mas não basta apenas "querer dizer", é preciso "poder dizer"; este é o terceiro desafio e também o mais difícil, pois o poder implica sempre uma rede de relações construídas num jogo muitas vezes velado. De nada vale ter o que dizer, de nada vale querer, se eu não posso dizer. Quantas vezes cada um de nós já se viu nessa frustrante condição de não poder dizer, muito embora querendo e tendo o que dizer? A seguinte citação de Foucault (2002, p. 37) justifica a interdição ou liberação da fala.

\section{[...] ninguém entrará na ordem do discurso se não satisfizer a certas exigências ou se não for, de início, qualificado para fazê-lo. Mais precisamente: nem todas as regiões do dis- curso são igualmente abertas e penetráveis; algumas são altamente proibidas (diferenciadas e diferenciantes), en- quanto outras parecem quase abertas a todos os ventos e postas, sem restrição prévia, à disposição de cada sujeito que fala.}

\section{Oralidade e escrita: encontros e desencontros}

Tendo em vista ser o homem, por natureza, falante e ouvinte, e não escritor e leitor, ele necessita ser iniciado na cultura escrita. A escrita rompe com a temporalidade da fala para constituir-se numa rede articulada, num texto tecido de forma aberta a uma gama de sentidos que se produzem no contexto de recepção mais do que no contexto da enunciação. A distância existente entre autor e leitor exige do autor uma representação imagética prévia do virtual leitor a quem se dirige, o qual é o seu "leitor ideal".

A dimensão visual e espacial da escrita, articulada à sua materialidade e inserção num suporte externo, tornou-a transportável e conservável, permitindo guardar as informações durante um tempo indeterminado. Isso modifica a natureza da comunicação, estendendo-a para além do simples contato pessoal, ao mesmo tempo em que transforma as condições de 
arquivamento da informação, colocando-a acessível àqueles que sabem ler um campo de conhecimento mais extenso.

O que podemos observar concretamente é que há uma interdependência entre oralidade e escrita. Elas constroem-se em reciprocidade, interpenetram-se e complementam-se. A escrita pode intensificar a oralidade ao extrair do contexto oral enunciados, analisálos e remodelá-los na cultura escrita, devolvendo-os em seguida ao contexto oral com vigor e força renovados. A oralidade pode intensificar a escrita, na medida em que só a virtual oralização faz do escrever um ato de significar, ou seja, só tem sentido escrever se existirem supostos virtuais leitores que irão dar ao texto os muitos sentidos possíveis, incorporando esses sentidos às suas falas (Orlandi, 2001).

Como todas as línguas que se manifestam nas modalidades escrita e falada, a língua portuguesa produz várias gramáticas, diferenciadas por recursos estilísticos próprios, que se comportam mais adequadamente em uma ou outra modalidade. Isso não significa, porém, que a fala e a escrita devam ser vistas de forma dicotômica, estanque, como era comum até há algum tempo e, por vezes, acontece ainda hoje. Segundo Marcuschi (1995, p. 13), "As diferenças entre fala e escrita se dão dentro do continuum tipológico das práticas sociais e não na relação dicotômica de dois pólos opostos".

O que se verifica, na verdade, é que existem textos escritos que se situam, na relação de continuidade, como mais próximos ao pólo da fala conversacional (bilhetes, cartas familiares, textos de humor, por exemplo), ao passo que existem textos falados que mais se aproximam do pólo da escrita formal (conferências, entrevistas profissionais, discursos religiosos e outros), sem se desprezar aqueles que transitam em um ou outro pólo em posições intermediárias. Nesse sentido, torna-se difícil sustentar a presença de características exclusivas de uma ou outra modalidade.

Na prática, entretanto, em virtude do valor social atribuído à língua escrita, costuma-se olhar a língua falada através das lentes de uma gramática projetada para a escrita. Nessa perspectiva, predomina uma visão preconceituosa da fala com base mais estrutural do que funcional (descontínua, pouco organizada, rudimentar, não-planejada), muito mais porque se constitui como a única forma de expressão verbal de sociedades ditas primitivas, de crianças em fase de aquisição ou de cidadãos pouco escolarizados do que pelo valor social intrínseco que os atos de fala representam.

Retornando à compreensão da natureza textual das duas modalidades, Koch (2007) chama atenção para o fato de que o texto falado apresenta uma sintaxe característica, contudo a sintaxe geral da língua serve-lhe de pano de fundo. Além disso, a escrita pode ser considerada estática - produto de um processo enquanto a fala se desenvolve durante o processo de comunicação, sendo assim dinâmica. Sobre esse aspecto, a autora remete-nos a Michael Halliday:

\footnotetext{
[...] capta bem essa diferença, utilizando a metáfora do quadro e do filme. Para o leitor, o texto se apresenta de forma sinóptica: ele existe, estampado numa página - por trás dele vê-se um quadro. Já no caso do ouvinte, o texto o atinge de forma dinâmica, coreográfica: ele acontece, viajando através do ar-por trás dele é como se existisse não um quadro, mas um filme. (Koch, 2007, p. 63)
}

Em outras palavras, foi a visão dicotômica de fala e escrita, amplamente divulgada, que fez a marcação estrutural das diferenças entre essas modalidades. Caracteriza-se a fala como contextualizada, implícita, redundante, não-planejada, com predominância do "modus pragmático", fragmentada, incompleta etc. Em contrapartida, a escrita é considerada descontextualizada, explícita, condensada, planejada, com predominância do "modus sintático" etc. Koch (2007) alerta, contudo, que nem todas essas características são exclusivas de uma ou outra das duas modalidades e que tais características foram sempre estabelecidas tendo por parâmetro o ideal da escrita.

Sabemos, na prática, que as relações entre fala $\mathrm{e}$ escrita não são óbvias nem lineares, pois elas, sem dúvida, refletem um constante dinamismo fundado no continuum que se manifesta entre essas duas modali- 
dades de uso da língua. Cabe ao professor direcionar seu trabalho no ensino de língua materna não para a polarização estanque entre o oral e o escrito, fortalecendo os preconceitos em torno da oralidade, mas que colabore para que os alunos percebam que a oralidade e a escrita são duas faces da mesma moeda da língua portuguesa, e que cada uma exerce diferentes papéis funcionais dentro dos vários contextos socioculturais de cada coletividade.

\section{Os caminhos da oralidade em EJA: questionamentos e novas leituras}

Os falares das pessoas analfabetas ou pouco escolarizadas são o canal autêntico de expressão da sua tradição cultural, de registro das suas experiências de vida, de viabilização de estratégias comunicativas a fim de lidar com as tarefas cotidianas. Podemos encontrar adultos pouco escolarizados que têm um excepcional domínio da expressão oral: contadores de histórias, poetas, repentistas, líderes populares. Entretanto, deparamo-nos com uma grande maioria que tem seu discurso marcado por experiências de privação, humilhação e isolamento, decorrentes do distanciamento da sua performance em relação aos parâmetros discursivos daqueles considerados socialmente bem-sucedidos.

Em especial, nas classes de EJA, percebe-se que a pedagogia se concentra quase exclusivamente nas atividades de letramento - ler e escrever são as habilidades prioritárias -, não considerando a pedagogia do desenvolvimento comunicativo na língua escrita e na oral como de igual valia para a formação integral do educando. Oficialmente, há o destaque para o trabalho pedagógico da oralidade, descrito na proposta curricular elaborada pelo Ministério da Educação (MEC) para o primeiro segmento de ensino fundamental na EJA:

O professor deve planejar estratégias para que os alunos experimentem e ampliem suas formas de expressão, promover momentos em que os educandos se expressem em pequenos grupos, em grupos maiores, em conversas com o professor. É necessário criar oportunidades de ouvir e falar, reelaborar argumentos a partir de novas informações, construir conceitos, incorporar novas palavras e significados, compreender e avaliar o que se ouve, chamando a atenção dos alunos para os diferentes modos de falar e os efeitos que podem provocar sobre os que recebem a mensagem. (Brasil, 1997, p. 53)

$\mathrm{Na}$ sala de aula, entretanto, observamos que as atividades de linguagem oral funcionam como formas de avaliação e "correção" dos falares regionais e sociais, na expectativa de que se aproximem da norma considerada gramaticalmente correta e mais alinhada aos padrões da língua escrita. Dessa forma, o texto oral funciona como pré-texto para a pedagogia do letramento e nunca como uma outra modalidade textual que se afirma adequadamente em diferentes situações sociais. Atitudes que levam a uma prática excessiva de correção da fala do aluno; sobretudo, em se tratando de um adulto, causam uma sensação de estranheza da própria língua materna, um distanciamento da sua cultura, uma crença da sua incompetência comunicativa que muitas vezes resultam no seu silenciamento. Os "comandos paragramaticais" - vozes de autoridade lingüística que circulam nos meios de comunicação e na nossa tradição pedagógica - reclamam que o brasileiro não sabe sua própria língua, mas Bagno (1999) defende os falares brasileiros como legítimos.

Esta língua é a língua que eu sei, é a língua que eu falo bem, e por ser a minha língua ela não é difícil. Difícil, sim, é uma língua que não tem eco na minha vivência, na minha experiência, que não traz à tona as minhas lembranças, que não abala os meus sentimentos, uma língua que não me fala ao coração, que não faz vibrar as cordas do meu ser. E no entanto é essa língua estranha, estrangeira, que vou ser obrigado, sujeitado e quase torturado a aprender.

O problema não está na aprendizagem de uma outra variante lingüística, considerada mais culta e de maior prestígio social, mas na postura que faz com que a variante popular seja desrespeitada, descartada, eliminada dos cenários escolares. Os livros didáticos apresentam exercícios com a finalidade exclu- 
siva de solicitar que os alunos saibam corrigir as variantes populares de acordo com a norma padrão. Os professores, da mesma forma, alegam que os alunos não falam direito e por isso têm dificuldade de escrever. Para superarmos essas falácias, pressupostos sem fundamentação nos estudos lingüísticos, precisamos compreender a linguagem nas suas múltiplas funcionalidades sociais. Tanto a língua escrita como a oral têm seus espaços de atuação, manifestando-se em diferentes graus de formalidade.

Os pilares de uma educação lingüística, teoricamente consistente, sustentam-se em duas bases: o desenvolvimento da competência comunicativa integral e o desenvolvimento da consciência metalingüística sobre o desempenho comunicativo de si próprio e dos seus interlocutores em textos orais e escritos. Entende-se competência comunicativa, na concepção de Hymes (1989), como a aquisição do conhecimento lingüístico com adequação aos contextos socioculturais de uma determinada comunidade lingüística em situações autênticas de interação verbal.

Em outras palavras, Schmidt (1983, p. 140) ressalta a contribuição de Michael Canale e Merrill Swain que destacam a inter-relação de quatro componentes associados à competência comunicativa: competência gramatical (domínio de vocabulário e de regras gramaticais básicas), competência sociolingüística (capacidade de tornar o discurso apropriado dentro de um determinado contexto sociocultural), competência do discurso (domínio das combinações entre formas gramaticais e significados a fim de manter a unidade do texto falado ou escrito) e competência estratégica (utilização de estratégias verbais e não-verbais a fim de compensar as "falhas" da comunicação). A consciência metalingüística, por sua vez, desenvolve-se a partir de atividades de observação do discurso de outros, de exercícios de experimentação de modelos variados de interação dialógica, de monitoração do seu próprio discurso visando à melhoria dos padrões de gramaticalidade, de adequação sociolingüística e de eficiência discursiva. A pertinência da construção de uma pedagogia da oralidade encontra apoio nas palavras de Gnerre
(2003, p. 61), ao discutir sobre a mediação entre a oralidade e a escrita:

É justamente esta fase de mediação que precisa ser fortalecida de várias formas: temos que tentar devolver o gosto e a confiança na oralidade, o prestígio da arte verbal, a discussão sobre as hipóteses relativas ao que seria a escrita, a leitura oral em voz alta de livros escritos e impressos e a discussão dos seus conteúdos, comparados com conteúdos de histórias da tradição oral. Todas estas, e outras, seriam as práticas necessárias para fortalecer ou até mesmo instituir a fase de mediação entre oralidade e escrita.

Muitos lingüistas brasileiros vêm contribuindo no campo de pesquisa que enfoca a interação em sala de aula, envolvendo os fundamentos teóricos da sociolingüística interacional, da análise da conversação e da análise do discurso. Contudo, a sala de aula de EJA ainda é um espaço pouco explorado, necessitando de estudos que analisem tópicos relevantes como: discurso pedagógico, interação/conversação em sala de aula, competência comunicativa em eventos de fala nas esferas pública e privada, letramento e oralidade na escola e na comunidade, diversidade lingüística/preconceito lingüístico/fracasso escolar, entre outros.

Avançamos nossa proposta ao idealizarmos uma pedagogia da oralidade em EJA que promova o desenvolvimento da competência comunicativa em ambientes fora da escola. Inspiramo-nos em depoimentos de alunos de EJA que apontam dificuldades de se expressar adequadamente em situações sociais várias, como, por exemplo, em uma entrevista de emprego, em idas a agências de serviços públicos para tirar documentos, em conflitos com vizinhos ou colegas de trabalho e em muitos outros eventos de fala. Nessa proposta, é possível trabalhar com situações simuladas por meio de diálogos situacionais - retirados de textos escritos ou orais encontrados na literatura, no cinema, no teatro, na televisão, na música - na intenção de analisar os conteúdos sociolingüísticos, incorporar estratégias comunicativas lingüísticas e extralingüísticas que colaborem com a intencionalidade do 
discurso, e ampliar seu repertório discursivo e sua competência comunicativa integral.

\section{Inconclusões}

O título da finalização deste artigo sugere a incompletude intrínseca a qualquer discurso dialógico/ dialético; nós nos disponibilizamos ao debate que venha a fortalecer a possibilidade de promover novas leituras em referência ao trabalho de oralidade em EJA. Asseguramos, desde já, a necessidade de produzir pesquisas aplicadas às experiências pedagógicas de EJA que envolvam três direções de enfoque: etnografias sobre eventos de letramento e de fala nas comunidades de origem dos alunos, estudos de pesquisa-ação sobre os padrões de interação em sala de aula e formulação de propostas que objetivem o desenvolvimento da competência comunicativa em situações sociais da vida fora da escola.

Retomando o compromisso de educação de Freire (1992, p. 116), ao ressaltar: "Precisávamos de uma pedagogia da comunicação, com que vencêssemos o desamor acrítico do antidiálogo", acreditamos que nossas intenções de construir um programa pedagógico da oralidade em EJA vão contribuir amplamente com a afirmação dos direitos lingüísticos do aluno como parte essencial do fortalecimento de identidades sociais, da formação de cidadania em uma sociedade democrática.

\section{Referências bibliográficas}

AUSTIN, John Langshaw. How to do things with words. New York: Oxford University Press, 1965.

BAGNO, Marcos. Que país? Que povo? Que língua? In: SEMANA DE LETRAS E ARTES, 3., 1999, Feira de Santana. Palestra... Feira de Santana: Universidade Estadual de Feira de Santana, 1999. Disponível em: <http://paginas.terra.com.br/educacao/ marcosbagno/art_que_pais_que_povo_que_lingua.htm $>$. Acesso em: 12 mar. 2006.

BAKHTIN, Mikhail. Marxismo e filosofia da linguagem. Hucitec: São Paulo, 1990.

BÍBLIA Sagrada. Trad. de Pe. Matos Soares. São Paulo: Paulinas, 1983.
BORTONI-RICARDO, Stella Maris. Nós cheguemu na escola, e agora? In: Sociolingüistica \& educação. São Paulo: Parábola Editorial, 2005.

BOURDIEU, Pierre. A economia das trocas lingüisticas. São Paulo: Editora da Universidade de São Paulo, 1998.

BRASIL. Ministério da Educação. Educação de jovens e adultos: proposta curricular para o $1^{\circ}$ segmento do ensino fundamental. São Paulo: Ação Educativa; Brasília: MEC, 1997. [Coordenação e texto final: Vera Maria Masagão Ribeiro]

CAVALCANTI, Marilda C. Um evento de letramento como cenário de construção de identidades sociais. In: COX, Maria Inês Pagliarini; ASSIS-PETERSON, Ana A. (Orgs.). Cenas de sala de aula. Campinas: Mercado de Letras, 2001. p. 105-24.

CHAUÍ, Marilena. Convite à filosofia. São Paulo: Ática, 2003.

FOUCAULT, Michel. A ordem do discurso. São Paulo: Edições Loyola, 2002.

FREIRE, Paulo. Pedagogia do oprimido. 18. ed. Rio de Janeiro: Paz e Terra, 1988.

Educação como prática de liberdade. 21. ed. Rio de Janeiro: Paz e Terra, 1992.

GERALDI, João Wanderley (Org.). O texto na sala de aula. Cascavel: Assoeste, 1984.

Portos de passagem. São Paulo: Martins Fontes, 1995.

GNERRE, Maurizio. Linguagem, escrita e poder. São Paulo: Martins Fontes, 2003.

HEATH, Shirley Brice. Ways with words - Language, life, and work in communities and classrooms. New York: Cambridge University Press, 1994.

HYMES, Dell. Foundations in sociolinguistics. An ethnographic approach. Philadelphia: University of Pennsylvania Press, 1989.

KLEIMAN, Ângela B. (Org.). Os significados do letramento: uma nova perspectiva sobre a prática social da escrita. Campinas: Mercado de Letras, 2001.

$\mathrm{KOCH}$, Ingedore Villaça. A inter-ação pela linguagem. 8. ed. São Paulo: Contexto, 2003.

O texto e a construção dos sentidos. 9. ed. São Pau-

lo: Contexto, 2007.

MAGALHÃES, Izabel. Práticas discursivas de letramento: a construção da identidade em relatos de mulheres. In: KLEIMAN, Angela (Org.). Os significados do letramento: uma nova perspectiva sobre a prática social da escrita. Campinas: Mercado de Letras, 2001. p. 201-235. 
MARCUSCHI, Luiz Antonio. Contextualização e explicitude na fala e na escrita. Recife: s. ed., 1995 (mimeo.).

MEY, Jacob L. As vozes da sociedade. Campinas: Mercado de Letras, 2001

MOTA, Kátia Maria Santos. A linguagem da vida, a linguagem da escola: inclusão ou exclusão? (uma breve reflexão lingüística para não lingüistas). Revista da FAEEBA Educação e Contemporaneidade, Salvador, v. 11, p. 13-26, jan./jun. 2002.

OGBU, John U. Cultural Diversity and School Experience. In: WALSH, Catherine E. (Ed.). Literacy as praxis - culture, language and pedagogy. Norwood: Alex Publishing Corporation, 1991. p. 25-50.

ORLANDI, Eni Puccinelli. Discurso e leitura. São Paulo: Cortez; Campinas: Editora da Unicamp, 2001.

A linguagem e seu funcionamento: as formas do discurso. São Paulo/Campinas: Pontes, 2003.

PHILIPS, Susan Urmston. The invisible culture - communication in classroom and community on the Warm Springs Indian Reservation. Prospect Heights: Waveland Press, Inc., 1993.

RAMOS, Graciliano. Entrevista em 1948. In:

Vidas secas. 102. ed. Rio de Janeiro: Record, 2007, contracapa.

SAUSSURE, Ferdinand de. Curso de lingüistica geral. São Paulo: Cultrix, 1975.

SCHMIDT, Richard W. Interaction, acculturation, and the acquisition of communicative competence: a case study of an adult. In: WOLFSON, Nessa; JUDD, Elliot (Eds.). Sociolinguistics and language acquisition. Rowley: Newbury House Publishers, 1983. p. $137-174$.

SOARES, Magda. Letramento - um tema em três gêneros. Belo Horizonte: Autêntica, 2003.

SOBRAL, Adail. Ato/atividade e evento. In: BRAIT, Beth (Org.). Baktin: conceitos-chave. São Paulo: Contexto, 2005. p. 11-36.

VYGOTSKY, Lev Semyonovich. Pensamento e linguagem. 2. ed. São Paulo: Martins Fontes, 1989.

WELLS, Gordon. The meaning makers - children learning language and using language to learn. Portsmouth: Heinemann, 1986.

KÁTIA MARIA SANTOS MOTA, doutora em estudos lusobrasileiros pela Brown University, nos Estados Unidos, é professora do Programa de Pós-Graduação Educação e Contemporanei- dade da Universidade do Estado da Bahia (UNEB), campus I Salvador. Publicou recentemente: As interações conversacionais em sala de aula (In: MERCADO, Luis Paulo Leopoldo; CAVALCANTE, Maria Auxiliadora da Silva (Orgs.). Formação do pesquisador em educação: profissionalização docente, políticas públicas, trabalho e pesquisa. Maceió: EDUFAL, 2007. p. 109-124); Mulheres brasileiras imigrantes nos Estados Unidos: (des)caminhos do bilingüismo em trajetórias de identidades (In: CAVALCANTI, Marilda C.; BORTONI-RICARDO, Stella Maris (Orgs.). Transculturalidade, linguagem e educação. Campinas: Mercado de Letras, 2007. p. 143-174); Lingua(gem) e cidadania em um mundo pluricultural: descompassos e desafios (In: LIMA JR., Arnaud Soares de; HETKOWSKI, Tânia Maria (Orgs.). Educação e contemporaneidade: desafios para a pesquisa e a pós-graduação. Rio de Janeiro: Quartet, 2006. p. 157-172); organizou com SCHEYERL, Denise Chaves de Menezes, Espaços lingüisticos: resistências e expansões (Salvador: EDUFBA, 2006). Pesquisadora na área de sociolingüística aplicada à educação. E-mail: motakatia@hotmail.com

JANINE FONTES DE SOUZA, mestre em educação pela Universidade do Estado da Bahia (UNEB), é professora de prática de ensino da mesma universidade, no campus XXIV - XiqueXique. Publicou recentemente: O texto nosso de cada dia (In: ENCONTRO DE PESQUISA EDUCACIONAL DO NORTE E NORDESTE - EPENN -, 18., 2007, Maceió. Anais... Maceió: Universidade Federal de Alagoas, 2007. 1 CD-ROM); A leitura da palavramundo: o mundo das palavras, as palavras no mundo (In: COLÓQUIO FORMAÇÃO DE EDUCADORES: Ressignificar a profissão docente, 2., 2006, Salvador. Anais... Salvador: Universidade do Estado da Bahia/Universidade Federal da Bahia, 2006. 1 CD-ROM); Eu falo, tu falas, nós escrevemos: diversidade lingüística e prática pedagógica. (In: ENCONTRO DE PESQUISA EDUCACIONAL DO NORTE E NORDESTE - EPENN -, 17., 2005, Belém. Anais... Belém: Universidade Federal do Pará, 2005. 1 CD-ROM). Pesquisadora na área de linguagem e educação. $E$ mail:nine_fontes@yahoo.com.br

Recebido em outubro de 2006 Aprovado em maio de 2007 
Janine Fontes de Souza e Kátia Maria Santos Mota

O silêncio é de ouro e a palavra é de prata? Considerações acerca do espaço da oralidade em educação de jovens e adultos

Este artigo objetiva estabelecer parâmetros comparativos sobre a escrita e a oralidade, com base nos estudos sociolingüísticos. Ao mesmo tempo, apresenta novas perspectivas sobre a pedagogia da oralidade em educação de jovens e adultos, vinculada às necessidades comunicativas dos alunos na sociedade contemporânea. Enfoca o diálogo, a interação verbal e a competência comunicativa como componentes essenciais da educação lingüística. Compreendendo a fala como ferramenta primordial para a expressão de pensamentos, crenças e atitudes, assim como espaço de fortalecimento de identidade e direito social na formação de cidadania, as autoras posicionam-se cri- 
ticamente sobre as práticas metodológicas do ensino da oralidade nas escolas.

Palavras-chave: educação de jovens e adultos; oralidade; interação

Silence is golden, the word is silver? Oral language in young and adult education

This article proposes to establish comparative parameters on the written word and orality based on sociolinguistic studies and, at the same time, to present new perspectives on the pedagogy of orality in adult and youth education, linked to the communication needs of students in contemporary society. It focuses on dialogue, verbal interaction and communication competence as essential components of linguistic education. Taking the spoken word as the primordial tool for expressing thoughts, beliefs and attitudes as well as a space for strengthening identity and social right in the formation of the citizenship, the authors take a critical position concerning the methodological practices of teaching orality in our schools.

Key words: adult and youth education; orality; interaction

\section{¿EI silencio es de oro, la palabra es}

de plata? Consideraciones a respecto del espacio de la oralidad en la educación de jóvenes y adultos Este artículo tiene por objeto establecer parámetros comparativos sobre la escrita y la oralidad, con base en los estudios sociolinguísticos. Al mismo tiempo, presenta nuevas perspectivas sobre la pedagogía de la oralidad en la educación de jóvenes y adultos, vinculada a las necesidades comunicativas de los alumnos en la sociedad contemporánea. Enfoca el diálogo, la interacción verbal y la competencia comunicativa como componentes esenciales de la educación linguística. Comprendiendo la habla como herramienta primordial para la expresión de pensamientos, creencias y actitudes, así como espacio de fortalecimiento de identidad y derecho social en la formación de la ciudadania, las autoras se posicionan de forma crítica sobre las prácticas metodológicas de la enseñanza de la oralidad en las escuelas.

Palabras claves: educación de jóvenes y adultos; oralidad; interacción 